\title{
Media Sosial Untuk Usaha Mandiri Pada Masa Pandemik Di Yayasan Baitul Karim
}

\author{
Eko Suharyanto ${ }^{1}$, Chrisantus Tristianto ${ }^{2}$, Imam Hidayat ${ }^{3}$, Yunus $^{4}$ \\ Program Sistem Informasi, Fakultas Teknik, Universitas Pamulang, Banten, Indonesia \\ Email: ${ }^{1}$ dosen01830@unpam.ac.id, ${ }^{2}$ dosen01513@unpam.ac.id, ${ }^{3}$ dosen02714@unpam.ac.id \\ ${ }^{4}$ dosen02687@unpam.ac.id
}

\begin{abstract}
Today's technological advances can take advantage of the internet and their mobile devices to develop online businesses so that they can drive a wider market. The implementation of this PKM is carried out, with 1) The purpose of training for the Baitul Karim Foundation community. 2) Train the Baitul Karim Foundation community to use this social media by selling online. One of the platforms is the Tokopedia seller, one of the features found in the Tokopedia company that functions as a supporter of business actors to facilitate product marketing throughout the archipelago. As for how to register our account on Tokopedia, Tokopedia has advantages in the components of reviews and complaints (UK), certification and security (SK), product prices (HP), product descriptions (DP), and transportation (TR). This gives enthusiasm to provide workshops to several sellers or sellers by selling online through social media and several platforms such as Facebook, Instagram at the Baitul Karim Foundation.
\end{abstract}

Keywords: Social Media, Tokopedia, Independent Business

\begin{abstract}
Abstrak
Kemajuan teknologi saat ini dapat memanfaatkan internet dan perangkat mobile mereka untuk mengembangkan bisnis secara online sehingga dapat mendorong pasar yang lebih luas. Pelaksanaan PKM ini dilakukan, dengan 1) Tujuan pelatihan bagi masyarakat Yayasan Baitul Karim. 2) Melatih komunitas Yayasan Baitul Karim menggunakan media sosial ini dengan berjualan secara online. Salah satu platformnya adalah penjual Tokopedia, salah satu fitur yang terdapat di perusahaan Tokopedia yang berfungsi sebagai pendukung para pelaku usaha untuk mempermudah pemasaran produk di seluruh nusantara. Adapun cara daftar akun kita di Tokopedia, Tokopedia memiliki keunggulan pada komponen ulasan dan keluhan (UK), sertifikasi dan keamanan (SK), harga produk (HP), deskripsi produk (DP), dan transportasi (TR). Hal ini memberikan semangat untuk memberikan workshop kepada beberapa penjual atau seller dengan berjualan secara online melalui media sosial dan beberapa platform seperti Facebook, Instagram di Yayasan Baitul Karim.
\end{abstract}

Kata Kunci: Media Sosial, Tokopedia, Usaha Mandiri

\section{A. PENDAhuluan}

Penguatan masyarakat melalui digitalisasi ilmiah dan teknologi untuk mengembangkan UMKM sangat penting di era informasi saat ini. Semakin banyak perusahaan kecil dan menengah yang berpartisipasi dalam ekonomi digital melalui broadband, e-commerce, media sosial, cloud, dan platform seluler. UKM dapat tumbuh lebih cepat, menjadi lebih inovatif dan kompetitif dalam hal pendapatan dan lapangan kerja dalam menghadapi komunitas bisnis ASEAN (Nugroho, 2020; Boiliu, F. M., \& Pasaribu, 2020). Konsep Local Economic Development (LED) menekankan pada pemanfaatan sumber daya, kapasitas, dan kompetensi lokal secara maksimal (Kusumawati, S,
2019, Haryono, \& Fathoni, 2017, Hadiyat, 2014). Pengembangan Ekonomi Lokal didefinisikan sebagai kolaborasi antara pemerintah, dunia usaha serta sektor non-pemerintah dan masyarakat untuk mengidentifikasi dan juga menggunakan sumber daya lokal daerah untuk mengoptimalkan dan menciptakan ekonomi lokal yang lebih baik dan lebih kuat dari sebelumnya (Narulita \& Koswara, 2021; Irawan, 2020; Kusumaningsih, 2021).

Pasca pandemi terdapat beberapa usaha yang melejit di tengah pandemi yaitu, penjualan masker kain, hand sanitizer, kuliner dengan berbagai kuliner yang unik dan murah, serta jasa kurir yang menyediakan jasa pengiriman barang karena banyak masyarakat yang enggan bepergian dan lebih memilih menggunakan jasa kurir untuk 
mengirim barang (Sholihah, 2021; Masrul, dkk, 2020).

Menjamurnya usaha kuliner di tengah pandemik dengan jenis makanan yang beragam membuat masyarakat semakin dimanjakan yang menyebabkan keinginan untuk berbelanja lebih tinggi. Melihat perubahan ini membuat kita berfikir bahwa pandemic covid-19 memberi dampak yang sangat besar dan komplek. Banyak yang kehilangan pekerjaan yang secara tidak langsung memacu masyarakat untuk menggali kemampuan dan skill diri, sehingga mendorong mereka untuk menciptakan usaha kecil-kecilan yang secara tidak langsung dapat memenuhi kebutuhan hidup masyarakat lainnya dan secara tidak langsung membuat kaum perempuan menjadi lebih produktif. Sebenarnya banyak pelaku UMKM yang belum memahami bagaimana cara menyusun Laporan Keuangan kegiatan usahanya, sehingga membutuhkan informasi keuangan yang sebenarnya.

Pergerakan dan perubahan aktivitas bisnis yang semakin cepat menuju digitalisasi memaksa para pelaku bisnis untuk beradaptasi dengan perubahan tersebut. Bagi perusahaan besar, perubahan pola bisnis yang mengarah pada proses digitalisasi tidak terlalu terbatas karena sifat perusahaan besar yang memiliki sumber daya yang memadai. Namun bagi UMKM, proses digitalisasi ini membutuhkan banyak persiapan. Banyak permasalahan yang dihadapi UMKM diantaranya kurangnya pengetahuan tentang cara mendirikan UMKM, kurangnya perizinan, sengketa hak atas kekayaan intelektual (HAKI) dan juga masalah yang paling mendasar adalah strategi pemasaran melalui media digital. Saat ini, peran teknologi informasi dalam dunia bisnis sangat berpengaruh, terutama dalam kaitannya dengan penjualan.

Pasca pandemi, ada beberapa bisnis yang meroket di tengah pandemi, yakni penjualan masker kain, desinfektan tangan, penawaran kuliner dengan aneka kuliner unik dan murah, serta jasa kurir yang menawarkan jasa pengiriman barang karena banyak masyarakat enggan untuk bepergian dan untuk pengiriman barang lebih memilih menggunakan jasa kurir. Menjamurnya berbagai jenis makanan oleh usaha kuliner di tengah pandemi semakin memanjakan masyarakat sehingga menimbulkan keinginan berbelanja yang semakin besar. Dengan adanya perubahan tersebut, menurut kami pandemi COVID-19 memiliki dampak yang sangat besar dan kompleks. Banyak yang kehilangan pekerjaan, yang secara tidak langsung mengarahkan masyarakat untuk menggali keterampilan dan kemampuan mereka sendiri, sehingga mendorong mereka untuk memulai usaha kecil yang secara tidak langsung dapat memenuhi kebutuhan orang lain dan secara tidak langsung membuat perempuan menjadi lebih produktif. Memang banyak pelaku UMKM yang tidak mengerti bagaimana menyusun laporan keuangan untuk usahanya sehingga membutuhkan informasi keuangan yang up-to-date.

Pemasaran media sosial adalah bentuk mempromosikan beragam konten bisnis dalam berbagai cara kepada pengguna media sosial. Kegiatan ini dilakukan untuk menemukan formula yang tepat dalam menyebarkan informasi yang dibutuhkan untuk mengarahkan tujuan bisnis dan peningkatan penjualan. Karena seiring dengan perkembangan zaman, minat beli konsumen banyak dipengaruhi oleh teknologi. Dimulai dengan munculnya teknologi Web 2.0 yaitu alat yang memudahkan orang untuk membuat dan mempublikasikan konten, berbagi ide, memilih yang disukai, dan merekomendasikan sesuatu kepada orang lain

Masa pandemi sebenarnya menawarkan peluang bagi usaha mandiri melalui pemanfaatan media sosial dan e-commerce. Dengan kemajuan teknologi saat ini, Anda dapat memanfaatkan internet dan perangkat seluler yang anda butuhkan untuk mengembangkan bisnis online Anda untuk melayani pasar yang lebih luas. Hal ini memberikan semangat peneliti untuk membantu banyak penjual atau seller dengan berjualan online melalui media sosial (Yunus, 2021; Yunus, 2019) dan berbagai platform seperti Tokopedia, Bukalapak dan Shopee, bahkan Facebook dan Instagram di Yayasan Baitul Karim. Hasil observasi dan penjelasan yang diberikan oleh Yayasan Baitul Karim terhadap penjualan produk secara online dijelaskan pada poin selanjutnya.

\section{B. METODE PELAKSANAAN}

Metode dan prosedur penyelesaian permasalahan yang dilakukan antara lain: 1 . Melakukan survey dan pengumpulan data. Survey dan pengumpulan data digunakan utuk mendapatkan informasi yang lengkap tentang kendala-kendala yang dihadapi pelaku usaha dalam memasarkan produk dilapangan. Teknik yang dilakukan dalam mengumpulkan data didapatkan melalui wawancara dengan pengrajin. Melalui kegiatan wawancara ini, didapatkan informasi terkait jumlah sepatu yang dapat diproduksi, jumlah follower di media sosial yang sebelumnya telah dimiliki oleh masing-masing pengusaha, kisaran jumlah calon konsumen potensial serta omset penjualan sebelum adanya pelatihan. 2 . Melakukan analisis hasil survey. Data yang didapatkan melalui wawancara kemudian selanjutnya akan dianalisis untuk menentukan langkah selanjutnya yang harus ditempuh oleh tim pengabdian demi menyelesaikan masalah yang dihadapi oleh pegusaha. 3. Mengadakan pelatihan e-commerce. Pelatihan ecommerce yang nantinya akan digunakan untuk memasarkan produk sepatu dilakukan dalam beberapa tahap. Tahapan pertama dimulai dengan perkenalan ragam jenis sosial media yang dapat digunakan untuk pemasaran 
online. Selanjutnya, pelaku usaha akan dilatih untuk dapat membuat akun pada masing-masing media sosial kemudian dilanjutkan dengan pelatihan cara mengoperasikannya. Beberapa jenis sosial media yang akan diajarkan dalam pelatihan ini antara lain adalah Facebook, Instagram dan Twitter. Apabila pelaku usaha telah mengusai pengoperasian beberapa sosial media, dalam tahapan selanjutnya pengusaha akan diminta untuk mengkombinasikan penggunaan beberapa sosial media dalam sekali pemasaran. 4. Metode yang digunakan pada tahap akhir adalah melakukan evaluasi untuk mengetahui peningkatan jumlah penjualan yang terjadi setelah diadakannya kegiatan pelatihan. Peningkatan dalam jumlah penjualan alas kaki berbahan kulit akan menjadi tolak ukur kesuksesan program pelatihan sosial media dalam meningkatkan omset penjualan.

Pelaksanaan PKM di di Yayasan Baitul Karim dilaksanakan pada tanggal 23 bulan oktober 2021 bertempat di Kelurahan Bambu Apus Kecamatan Pamulang sesuai dengan kondisi yang ada di lapangan. Setelah kegiatan pengabdian kegiatan masyarakat Yayasan Baitul Karim selesai dilakukan, tahap selanjutnya akan dilakukan pembuatan laporan akhir dan presentasi sebagai laporan tugas akhir kegiatan PKM dilaksanakan. Adapun pelaksanaan:

1. Menjelaskan kepada masyarakat Yayasan Baitul Karim tujuan pelaksanaan pelatihan Program Pelatihan ini adalah pembekalan melalui dua tahap antara pertama, pembekalan materi secara tutorial disertai diskusi.

2. Melatih masyarakat Yayasan Baitul Karim memanfaatkan media sosial ini dengan berjualan online. Target dan luaran yang ingin dicapai dari program ini adalah menghasilkan seorang wirausahawan baru mandiri yang berbasis iptek di industri rumahan pada saat pandemik COVID-19.

\section{HASIL DAN PEMBAHASAN}

Salah satu cara nya dengan memanfaatkan e-commerce, salah satu yang akan dibahas adalah Tokopedia Seller.

Tokopedia seller adalah salah satu fitur yang terdapat pada perusahaan tokopedia yang difungsikan sebagai platform pendukung untuk para pelaku usaha memudahkan pemasaran produknya ke seluruh nusantara. Adapun cara mendaftar akun kita dalam di Tokopedia,

1. Mendaftar akun baru dengan menggunakan akun google ataupun no telepon

2. Login dengan akun facebook atau google ataupun nomor telepon yang sebelumnya sudah didaftarkan.

Tokopedia memiliki keunggulan pada komponen ulasan dan keluhan (UK), sertifikasi dan keamanan (SK), harga produk (HP), deskripsi produk (DP), dan transportasi (TR). Nurul et al. (2019) menjelaskan jika faktor terpenting pada penjualan melalui lokapasar Tokopedia adalah ulasan merupakan faktor terpenting dibandingkan jumlah pengunjung, reputasi produk dan gold badge. Ini berarti mendukung jika ulasan dan keluhan pada Tokopedia merupakan komponen unggul. angsangan pemasaran yang menarik konsumen untuk membeli melalui lokapasar Tokopedia. Rangsangan itu antara lain: produk lengkap dan praktis, harga yang murah, pengiriman yang cepat dengan banyak pilihan, banyaknya promo menarik, respon penjual yang baik dengan review dan foto yang terlihat, dan proses cepat sesuai harapan. Ini menunjukkan kewajaran jika keunggulan pada Tokopedia berupa harga produk, deskripsi produk dan transportasi. Selain itu, tidak dipungkiri sertifikasi dan keamanan, dan ulasan menjadi komponen penting pada Tokopedia.

Memanfaatkan platform seperti Tokopedia, perangkat yang dimiliki Tokopedia untuk mengembangkan usaha yang dimiliki secara online sehingga memungkinkan pencapaian pasar yang lebih luas. Selain itu, peneliti memberikan pendampingan terhadap beberapa penjual atau seller dengan berjualan online melalui sosial media maupun beberapa platform seperti facebook, instagram. Tahap awal pemateri berbagi cerita terkait pembukaan toko online shop di beberapa platform, setelah itu beberapa orang merasa tertarik. Kemudian mereka belajar membuka toko dan produk-produk yang mereka punya, dengan memanfaatkan secara maksimal terhadap sumber daya alam, kapasitas dan keterampilan yang ada di daerah. Tujuannya adalah mengoptimalkan dan menciptakan perekonomian lokal yang lebih baik dan lebih kuat dari sebelumnya. Beberapa produk yang ditawarkan teknik/cara menawarkan dagangan/jualan di media sosial.

Menariknya, jika ditelaah lebih dalam di tiga bengkel pasar tersebut, didapat dalam bentuk potongan yang bisa menjadi satu komponen yang sama. Dari ketiga bengkel pasar tersebut diperoleh komponen yang sama yaitu: ulasan dan keluhan (UK) dan transportasi (TR). Seperti yang sudah dibahas sebelumnya, baik ulasan maupun keluhan dan transportasi selalu menjadi pertimbangan utama di Tokopedia.

Memanfaatkan peranan internet dan perangkat mobile yang dimiliki untuk mengembangkan usaha yang dimiliki secara online sehingga memungkinkan pencapaian pasar yang lebih luas. Hal ini memberikan semangat untuk memberikan workshop terhadap beberapa penjual atau seller dengan berjualan online melalui sosial media maupun beberapa platform seperti facebook, Instagram di Yayasan Baitul Karim. Masa pandemi sebenarnya memberikan peluang untuk usaha mandiri dengan memanfaatkan Media Sosial dan ecommerce. Dengan kemajuan teknologi saat ini 
dapat memanfaatkan peranan internet dan perangkat mobile yang dimiliki untuk mengembangkan usaha yang dimiliki secara online sehingga memungkinkan pencapaian pasar yang lebih luas.

Dalam kehidupan sehari-hari kita tidak asing dengan jual beli, di mana melibatkan penjual yang melakukan penjualan dan pembeli yang sebagai pembeli terhadap barang atau jasa yang dijual oleh si penjual tersebut. Barang-barang atau jasa dalam penjualan akan dijual dengan menggunakan nilai dan harga tertentu. Dalam kehidupan sehari hari, penjualan dibedakan menjadi dua, yaitu penjualan secara langsung dan penjualan secara tak langsung. Penjualan secara langsung adalah kegiatan menjual barang atau jasa yang melibatkan penjual dan pembeli atau konsumen dan kedua pihak tersebut berhadapan langsung di tempat dan waktu yang telah disepakati bersama. Dalam penjualan langsung, maka si penjual akan mempromosikan barang atau jasa tanpa bantuan pihak lain, jadi semuanya ditangani sendiri oleh si penjual. Berbeda halnya dengan penjualan langsung yang mana penjual sendiri yang mempengaruhi konsumen untuk tertarik membeli produknya, maka penjualan secara tidak langsung merupakan kegiatan menjual barang atau jasa yang melalui media perantara yang bersifat untuk mempromosikan barang atau jasa tersebut kepada para pembeli atau konsumen sehingga mereka terpengaruh untuk membelinya. Media yang digunakan tersebut biasanya melalui iklan, katalog atau online via internet. Dari hal tersebut, maka dapat juga ditarik sebuah pengertian penjualan yaitu kegiatan yang menjual barang atau jasa kepada pembeli baik dilakukan sendiri oleh si penjual ataupun melalui media perantara. Dalam kehidupan sehari-hari, pengertian penjualan secara umum adalah menjual barang atau jasa yang melibatkan penjual dan pembeli. Sehingga penjualan sangat berperan penting dalam siklus perekonomian. Adapun peran penjualan bagi perekonomian suatu negara adalah memperlancar peredaran mata uang, menyalurkan hasil produk berupa barang atau jasa dari produsen ke konsumen, memenuhi kebutuhan konsumen yang berarti membantu negara dalam memenuhi kebutuhan hidup masyarakatnya

Hal ini memberikan semangat untuk memberikan pendampingan terhadap beberapa penjual atau seller dengan berjualan online melalui sosial media maupun beberapa platform seperti Facebook dan Instagram. Tahap awal berbagi cerita terkait pembukaan toko online shop di beberapa platform, setelah itu beberapa orang merasa tertarik

Kemudian mereka belajar membuka toko dan produk-produk yang mereka punya, dengan memanfaatkan secara maksimal terhadap sumber daya alam, kapasitas dan keterampilan yang ada di daerah. Tujuannya adalah mengoptimalkan dan menciptakan perekonomian lokal yang lebih baik dan lebih kuat dari sebelumnya.

Selain berbelanja lebih mudah dan simple, berbelanja online memberikan banyak pilihan, dalam sekali klik kita bisa menemukan berbagai macam pilihan produk dengan harga yang beragam, dan kita bisa memilih harga termurah dari produk yang ingin kita beli, melakukan pembayaran via online dan tinggal menunggu barang diantar ke alamat masing-masing.

Bisnis online semakin di gandrungi dan semakin tinggi peminatnya di saat pandemik seperti saat ini. Banyak masyarakat yang beralih ke bisnis online. Beberapa keuntungan yang di rasakan memilih bisnis online di saat pandemi yaitu, menghindari kontak langsung dengan orang lain, menghindari resiko penularan melalui barang, mudah menemukan barang yang diinginkan, pembayaran dapat di lakukan secara online tanpa harus kontak langsung dengan penjual dan promo berupa potongan harga yang membuat kita berbelanja lebih hemat. Hal ini memberikan manfaat dan keuntungan yang menyebakan banyak pelaku usaha beralih ke ecommerce. komputer sebagai perantara transaksi bisnis.

Selain itu, Terhitung sampai bulan Januari 2018, Blibli menjadi E-Commerce yang memiliki followers terbanyak, yaitu 467,771, diikuti oleh Lazada 332,098 dan OLX 205,482. Di sini, kami tidak hanya memantau berapa jumlah pengikut dari sebuah brand, tetapi kami juga memantau bagaimana jumlah pengikut tersebut bisa berkembang dalam waktu satu bulan.

Di balik ketiga brand sebelumnya yang memuncaki posisi 3 besar dengan jumlah pengikut terbanyak, nyatanya perkembangan jumlah pengikut tercepat dalam waktu 1 bulan adalah Shopee dengan angka $4.88 \%$. Artinya, dalam jangka waktu 1 bulan tersebut, Shopee berhasil membangun komunitas mereka di media sosial Twitter lebih cepat dan lebih efektif dibandingkan dengan brand E-Commerce lainnya. Selain Shopee, E-Commerce lainnya yang memiliki nilai Auidence Growth yang tinggi adalah JD.ID dengan $4.02 \%$ dan Tokopedia dengan $1.40 \%$. Hal lainnya yang dipantau adalah bagaimana para E-Commerce membuat konten sekaligus pula dengan seberapa efektif konten-konten tersebut bisa menarik perhatian pengguna media sosial (Engagement).

Pada media sosial Twitter, Blibli menjadi ECommerce yang paling banyak membuat konten, yaitu dengan jumlah 331 Tweets, diikuti oleh Bhinneka dengan 161 Tweets dan Bukalapak dengan 158 Tweets. Di sisi lain, Lazada memimpin dengan jumlah interaksi dan rata-rata interaksi terbanyak, 6,966 Retweet, 4,446 Favorite, 75 Average Retweet dan 48 Average Favorite. Top Post Made Twitter E-Commerce bulan Januari ini adalah Tweet dari Tokopedia dengan jumlah 1,512 Engagement (Januari 2018). 
Konten ini berupa video dengan tipe edukasi dan merupakan bagian dari Campaign. ECommerce Brand Community Facebook Selain Twitter, ternyata Facebook pun masih sangat dioptimalkan oleh para pegiat E-Commerce pada bulan Januari 2018 ini. Untuk media sosial Facebook, Lazada menjadi E-Commerce yang memiliki pengikut terbanyak dengan jumlah 21,641,121 Fans, diikuti oleh OLX dengan 8,008,495 Fans dan Zalora 6,990,087 Fans. Akan tetapi, pada bulan Januari, Audience Growth dari Shopee memiliki nilai paling tinggi di media sosial Facebook, dengan angka $12.54 \%$, diikuti oleh Tokopedia dengan $9.28 \%$ dan JD.ID $8.50 \%$.

Top Post Made E-Commerce di media sosial Facebook adalah konten yang dibuat oleh Lazada. Konten berisikan aktivasi LazadaID dengan menebak warna Handphone Infinix Zero5. Konten ini bersifat promosi dan berhasil mendapatkan 681 Engagement.

Dalam membangun brand Community di media sosial, jumlah Audience saja tidak bisa menjadi faktor kesuksesan sebuah brand dalam membangun komunitas. Parameter lainnya yang harus diperhatikan adalah perihal konten. Dalam hal ini, pembuatan konten harus bisa membangun nilai Engagement yang tinggi, sehingga komunitas yang sudah dibuat bisa terus berkembang. Setelah mengetahui konten apa yang ingin didistribusikan melalui media sosial, perhitungan Audience Growth pun perlu diperhatikan. Parameter keberhasilan dalam membangun Brand Community di media sosial adalah keefektifan konten yang dibuat sehingga bisa membuat pembaca menjadi pengikut setia dari media sosial tersebut. Dilihat dari kesuksesan E-commerce dalam membuat brand community, hal pertama yang harus dilakukan adalah membuat rencana distribusi konten dengan baik. Dalam hal ini, yang lebih difokuskan lagi adalah tipetipe konten yang ingin disampaikan ke pada para pengguna media sosial. Bukan menjadi rahasia lagi bahwa dalam Content Marketing, kita harus menjual produk dengan cara soft selling dan membuat orang merasa sangat perlu untuk membeli produk yang ditawarkan seningga meningkatkan omset penjualan bagi perusahaan. Perlunya dibuat beberapa macam tipe konten, seperti konten yang membuat orang ingin berkomentar, konten yang bersifat edukasi, konten menghibur, konten inspirasi bahkan sampai konten yang berbentuk promosi atau kuis berhadiah. Tipetipe konten tersebut adalah tipe konten yang berhasil dilakukan oleh para E-Commerce besar di Indonesia dalam menggaet pengguna media sosial menjadi komunitas mereka. Komunitas ini menjadi sangat penting karena dengan adanya komunitas, setiap informasi yang diberikan oleh masing- masing brand akan lebih mudah tersampaikan, bahkan tersebar ke masingmasing target audiencenya.

\section{PENUTUP}

\section{Simpulan}

Tokopedia seller adalah salah satu fitur yang terdapat pada perusahaan tokopedia yang difungsikan sebagai platform pendukung untuk para pelaku usaha memudahkan pemasaran produknya ke seluruh nusantara. Adapun cara mendaftar akun kita dalam di Tokopedia, 1) Mendaftar akun baru dengan menggunakan akun google ataupun no telepon. 2) Login dengan akun facebook atau google ataupun nomor telepon yang sebelumnya sudah didaftarkan. Alasannya, Tokopedia memiliki keunggulan pada komponen ulasan dan keluhan (UK), sertifikasi dan keamanan (SK), harga produk (HP), deskripsi produk (DP), dan transportasi (TR). Hal ini memberikan semangat untuk memberikan workshop terhadap beberapa penjual atau seller dengan berjualan online melalui sosial media maupun beberapa platform seperti facebook, Instagram di Yayasan Baitul Karim. Masa pandemi sebenarnya memberikan peluang untuk usaha mandiri bahkan memanfaatkan media sosial.

\section{Saran}

Dengan memanfaatkan IPTEK dengan dimasa pandemik, penjual atau seller dengan berjualan online melalui sosial media maupun beberapa platform Tokopedia bahkan facebook, Instagram, lebih memudahkan para penjual bahkan bisa menjauh wilayah lebih luas.

\section{Ucapan Terima Kasih}

Penulis dengan segala kerendahan hati menyampaikan ucapan terima kasih kepada Bapak Dede Supriyadi, S.Kom,. M.Kom, selaku Ketua Prodi Sistem Informasi dan H. Asep Wahdiana, S.Kom, sebagai ketua Yayasan Baitul Karim.

\section{E. DAFTAR PUSTAKA}

Boiliu, F. M., \& Pasaribu, M. M. (2020). Peran Pendidikan Agama Kristen di Gereja Terhadap Pemberdayaan Ekonomi Kreatif Jemaat di Era Digital. Jurnal Pengabdian Tri Bhakti, 118-132.

Hadiyat, Y. D. (2014). Kesenjangan Digital di Indonesia (Studi Kasus di Kabupaten Wakatobi). Jurnal Pekommas, 17(2), 81-90.

Haryono, A. T., \& Fathoni, A. (2017). Potensi Batik Lasem Sebagai Upaya Pengembangan Ekonomi Kreatif Untuk Meningkatkan 
Keunggulan Kompetitif Berkelanjutan di Kecamatan Lasem Kabupaten Rembang. Jurnal Ekonomi dan Bisnis Kontemporer, 3(2).

Irawan, E. (2020). Pembangunan Pedesaan Melalui Pendekatakan Kebijakan Local Economic Development Sebagai Upaya Peningkatan Daya Saing Desa. Nusantara Journal of Economics, 2(02), 38-52.

Kusumawati, S. (2019). Hubungan antara Modal Sosial dengan Difusi Inovasi Sebagai Basis Pengembangan Ekonomi Lokal. GEOPLANART, 2(1), 36-47.

Kusumaningsih, C., Syahadati, E., Susanti, E., \& Kurniawati, T. (2021). PELATIHAN ENGLISH FOR MARKETING PADA KELOMPOK P3MM DESA PAL IX KABUPATEN KUBU RAYA. GERVASI: Jurnal Pengabdian kepada Masyarakat, 5(2), 242-252.

Masrul, M., Abdillah, L. A., Tasnim, T., Simarmata, J., Daud, D., Sulaiman, O. K., ... \& Faried, A. I. (2020). Pandemik COVID-19: Persoalan dan Refleksi di Indonesia. Yayasan Kita Menulis.

Narulita, G., \& Koswara, A. Y. (2021). Penentuan Faktor Pengembangan Ekonomi Lokal Industri Mebel di Kecamatan Gadingrejo
Kota Pasuruan. Jurnal Teknik ITS, 9(2), D59D64.

Nugroho, R. H., \& Andarini, S. (2020). Strategi Pemberdayaan UMKM di Pedesaan Berbasis Kearifan Lokal di Era Industri 4.0 Menuju Era Society 5.0. Jurnal Bisnis Indonesia, 1(01).

Sholihah, I. (2021). Pendampingan Pemanfaatan Media Sosial Dan E-Commerce Sebagai Peluang Usaha Mandiri pada Masa Pandemi Covid-19 di Desa Pandansari Kecamatan Poncokusumo Malang. Khidmatuna: Jurnal Pengabdian Kepada Masyarakat, 2(1), 21-31.

Yunus, A. (2019, April). Pengaruh TI Media Sosial Terhadap Prestasi Belajar Pendidikan Agama Islam Peserta Didik di SMP Negeri 3 Mappadeceng Kabupaten Luwu Utara. In ESIT (Vol. 14, No. 1, pp. 16-25).

Yunus, Y., Raharjo, S., Handayani, M., Arifah, N., Rafli, R., Sitepu, N., ... \& Saleha, W. I. (2021). THE ROLE OF SOCIAL MEDIA IN THE ERA OF DIGITAL TRANSFORMATION AS A MEANS OF COMMUNICATION KARANG TARUNA COMMUNITY KAMPUNG PARUNG SERAB CILEDUG. International Journal of Engagement and Empowerment, 1(1), 1-5. 